\section{British echo US boycott of star wars research}

More than 40 British universities have applied to participate in the research programmes of the US Strategic Defense Initiative (SDI) and six are involved in the nine major contracts so far awarded in the United Kingdom, benefiting from a share of a budget that now totals $£ 25.9$ million.

The figures are those of the Ministry of Defence's SDI Participation Office in London as a response to a proposed boycott of the project by half of Britain's academic physicists, who publicly voiced their disapproval of the programme last weekend. The physicists were highly critical of the value of SDI research, though not objecting to defence-related programmes in general.

The British SDI boycott pledge, signed by 545 researchers including three Nobel laureates in physics and 25 Fellows of the Royal Society, is meant to endorse the stand taken by academic researchers in the United States. More than 7,000 academics have signed the US pledge, among them 3,700 science and engineering profesors and senior researchers, as well as 57 per cent of physics faculties at the top 20 research universities.

Neither the US nor the British signatories will accept or solicit funds for SDI research. According to the British partici-

\section{Missing — not dead}

DR Mohammed Younis Akbari, an Afghani nuclear physicist, who was sentenced to death by a revolutionary court in May 1984, is apparently still alive. A message from a fellow-prisoner relayed to Europe last month claims that Dr Akbari is still in prison, although no details are available about the conditions under which he is being held.

Akbari was sentenced on charges of participating in an illegal political organization and of receiving money from the People's Republic of China to buy arms. He was, in fact, a member of the Rehai-i ('freedom' group) led by a Dr Faiz. According to Akbari, it was Faiz who was offered, and may have accepted, money from the Chinese. He said he had travelled to China, but only for medical treatment.

At the time of his arrest and conviction, Western human rights campaigners pleaded for clemency on his behalf. The latest news, sparse though it is, and the improved situation in Afghanistan (as evidenced by the withdrawal of 8,000 Soviet troops) inspired the establishment, last month, of a new "Akbari Clemency Group".

Vera Rich pants in the weekend's meeting, their support is necessary to prevent their US colleagues from being isolated and pressurized into unacceptable research programmes. They say the pledge is initially meant to "document and publicize" the scale of opposition to the SDI programme by academic researchers, science and engineering lecturers and graduate students.

They further claim that the boycott will impede the development of what they believe to be a dangerous programme and will alert the scientific community to the role it has been asked to play in this "fraudulent peace shield".

It will also serve, they say, as a means of fostering discussion among researchers about SDI and the political profile that has been forced on the work of those already engaged on the programme. The British organizers have called on those now involved in research to think again and withdraw from the programme.

The British pledge reads: "We, the undersigned, believe that the Star Wars programme is technically dubious. An anti-ballistic missile defence system of sufficient reliability to defend populations against a Soviet first strike is not technically feasible in the foreseeable future . . . According, as working scientists, we will not apply for or accept support from the Strategic Defense Initiative Organization, which funds Star Wars research. We encourage other scientists and technical personnel to join us in refusing to cooperate with this deeply misguided and enormously expensive programme." Bill Johnstone - Tim Beardsley adds from Washington: The SDI boycott originated in the United States, principally on the campuses of Cornell University and the University of Illinois at Urbana-Champaign. The wording is essentially the same as the British version, committing signers of the pledge neither to solicit nor to accept funds for research related to SDI.

Separately, an open letter to Congress expressing "great reservations" about the wisdom of pursuing SDI has been signed by more than 2,000 researchers in industry and at national laboratories.

It is hard to estimate how far SDI research has actually been affected by the pledge, but John Kogut, a physics professor at the University of Illinois and one of the instigators of the campaign, points out that at Cornell University, 52 per cent of signatories had previously accepted support from the Department of Defense and so were potential SDI researchers.

The Department of Defense has said it has no shortage of good research propo-
Soviet Union Planning the
riposte to SDI

THE Soviet Union would take "adequate but not identical" countermeasures if the United States decided to deploy its Strategic Defense Initiative (SDI), Mr Gennadii Gerasimov, head of the information directorate of the Soviet Ministry of Foreign Affairs, announced last week. He suggested that a financial analysis for such measures had already been carried out. The cost, Gerasimov said, works out significantly less than that of the SDI programme and quite within Soviet capabilities. Some scientists, he stated, put it as low as 5 per cent of the calculated US expenditure on SDI.

Soviet spokesmen, both before and after the Reykjavik talks, have been careful to stress that the Soviet Union has no SDItype programme of its own. Since Reykjavik, however, there have been several indications in the Soviet media that the Soviet Union is prepared to undertake appropriate anti-SDI measures. Interviewed on Soviet television, Academician Konstantin Frolov, vice president of the Soviet Academy of Science, warned that "if the United States goes beyond the conditions of laboratory research on new types of weapons under the SDI programme, then of course the scientists of the Soviet Union will find the same approaches, and, of course these chances will always even out"

The relationship between Frolov's "similar approaches" and Gerasimov's "adequate but not identical" approach is not clear; Gerasimov is particularly insistent that the Soviet Union has no plans to work on a nuclear-pumped laser. He told Pravda last week that it would in any case be impossible to carry out such research as the Soviet Union has declared a moratorium on nuclear tests.

This moratorium is, of course, one of Mr Gorbachev's most valuable cards in the negotiating process, and not one he is likely to abandon lightly. Whatever form counter-SDI measures may take, it seems unlikely, to judge from Gerasimov, to be laser-based.

Vera Rich

sals. But the pledge has demonstrated the extent of opposition on campuses in the United States, and the SDI organization has grown noticeably more reticent about research contracts with academics.

Kogut, who has lectured on SDI several times in Britain, says the idea for a British version of the pledge arose out of discussions between him and Ann Davis of the University of Cambridge, among others. Kogut has hopes of taking the pledge to other countries also, and says support is particularly strong in West Germany. 